\title{
Folk medicinal plant mixtures: Establishing a protocol for further studies
}

\author{
Airy Gras ${ }^{\mathrm{a}, *}$, Montse Parada ${ }^{\mathrm{a}}$, Montse Rigat ${ }^{\mathrm{a}}$, Joan Vallès ${ }^{\mathrm{a}, \mathrm{b}}$, Teresa Garnatje
}

${ }^{a}$ Laboratori de Botànica (UB) - Unitat associada al CSIC, Facultat de Farmàcia i Ciències de l'Alimentació - Institut de Recerca de la Biodiversitat (IRBio), Universitat de Barcelona, Av. Joan XXIII 27-31, 08028 Barcelona, Catalonia, Spain

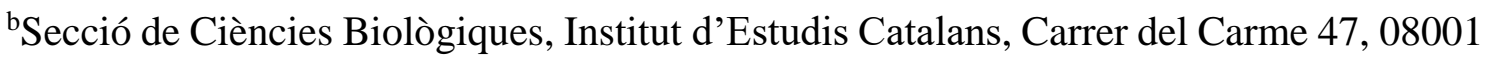
Barcelona, Catalonia, Spain

'Institut Botànic de Barcelona (IBB-CSIC-ICUB), Passeig del Migdia s.n., Parc de Montjuïc, 08038 Barcelona, Catalonia, Spain

*Corresponding author: Airy Gras (agras@ub.edu), +34-934024490

\begin{abstract}
Ethnopharmacological relevance: Most ethnobotanical research bases its analyses on individual taxa catalogues and their uses, rather than on mixtures. However, mixtures constitute an important chapter of our different lines of research and they represent a large volume of information. The relevance of these data in folk medicine could be explained as a response to the cure of multicausal etiology diseases or by a possible polyvalent effect of the mixture as opposed to the effect of each taxon alone.

Aims of the study: The main goals are: i) to perform qualitative and quantitative analyses of these mixtures; ii) to carry out a comparison among the mixtures in two Catalan territories and their floristic composition; iii) to assess the worth of families association; and, iv) to evaluate whether the plants claimed to be used in mixtures have contraindications or possible negative interactions according to phytopharmaceutical literature. The ultimate goal is to test a protocol that can be implemented in similar studies.
\end{abstract}

Materials and Methods: We have used data on medicinal plant mixtures obtained from two extensive ethnobotanical field studies carried out in two Catalan districts, Alt 
Empordà and Ripollès. The quantitative analyses by means of descriptive statistics were carried out with Excel. New contributions like the implementation of the Shannon index to quantify the diversity of families in plant combinations, the creation of a new index to calculate the taxon importance in mixtures, or the use of a social network analysis to study the connection between botanical families have been employed in this work.

Results: In total, a set of 484 mixtures from Alt Empordà and Ripollès (Catalonia, Iberian Peninsula) have been analysed: 462 for human use and 22 for veterinary. Thymus vulgaris and Rosmarinus officinalis are among the most commonly used species in mixtures. The aerial part of the plant is the most used, and the anticatarrhal usage is the most frequent in both territories. A wide diversity of families has been observed in mixtures and reflects a strong bond between the number of taxa and the number of families in each mixture, being almost equal to one. The Shannon diversity index applied to mixtures has the maximum value at 0.86 . No exclusive plants are used in mixtures, as reflected on the index of taxon usefulness in mixtures (ITUM), proposed in the present work. The association of families is strong between Lamiaceae (12.12\%) and Asteraceae with Lamiaceae (11.69\%). Finally, the informant consensus factor (0.85) reflects the strong consistency of data reported by the interviewees.

Conclusions: The present analysis has confirmed that it is possible to study the data of plants in mixtures as thoroughly as when they are considered in isolation in an ethnofloristic catalogue, and maybe this kind of ethnobotanical investigation could be a first step for future pharmacological studies that may result in a relevant complement to the current phytotherapy market.

Key words: Alt Empordà; Catalonia; ethnobotany; index of taxon usefulness in mixtures (ITUM); medicinal plant use; mixtures; Ripollès.

\section{Introduction}

Although mixtures constitute an important part of ethnobotanical research, they are often presented as descriptive information without being analysed. This fact is reflected in ethnopharmacological scientific publications that only in a few studies have considered plant combinations, limited in these few cases to a superficial analysis of data (Akerreta et al., 2007; Bonet and Vallès, 2002; Parada et al., 2009; Rigat et al., 2007). The lack of a protocol may be the reason for the scarcity of studies dealing with mixtures, since a 
large amount of data make their analysis difficult. Nevertheless, plant mixtures should play a highly relevant role in the recently developed approaches that include ethnobotany and 'omic' techniques to lead to a new generation of plant-derived drugs (Garnatje et al., 2017; Ulrich-Merzenich et al., 2009).

We consider a mixture as a portion of matter consisting of two or more components, in varying proportion, which retain their own properties. The concept of mixing plants to make a more effective poison or medicine is an ancient and very popular tradition: some famous examples are the Ayurveda, Traditional Indian Medicine, with some preparations with 70 plant taxa (Ayurvedic Formulary India, 1978) or the hallucinogenic beverage prepared for spiritual-healing rituals in the Amazon jungle, including ayahuasca (Banisteriopsis caapi (Spruce ex Griseb.) Morton), described by R.E. Schultes in 1979 (Hofmann and Schultes, 1982).

The therapeutic efficacy of certain mixtures of plants as opposed to their isolated components is well known and documented, and it is becoming increasingly clear that multifactorial diseases exist (e.g. cancer, cardiovascular or rheumatic diseases), which can be treated more effectively with the right combination of drugs (Ulrich-Merzenich et al., 2009; Wagner and Ulrich-Merzenich, 2009). Currently, traditional medicine is mainly used for chronic illnesses with a multiple cause etiology, in order to reduce symptoms and improve the quality of life in a cost-effective way (Gurib-Fakim, 2011), so that using mixtures would seem particularly appropriate.

The recurrent idea of the use of plant mixtures can be explained for different reasons: one could be, simply, the improvement of the taste of the preparation, and another, a polyvalent effect. Along this second line we can consider also the idea of synergism. This hypothesis (Corning, 1983), states that synergies are the source of all evolutionary processes and are represented in many disciplines. The author defines this phenomenon as the interaction of discrete agents such that the total effect is greater than the sum of the individual effects.

Also Gaddum (1940) and later Berenbaum (1989) worked along the same route with the isobole diagram. They argue that strengthening synergy exists when the effect of a combination is greater than the sum of their components administered separately. A clear example of this is the intrinsic content of plants, mixtures of different chemical compounds that may act individually, additively or in synergy to improve health (GuribFakim, 2011), and these mixtures of bioactive compounds in botanical drugs are widely claimed to be superior over monosubstances (Gertsch, 2011). One example is the 
apparently synergistic role of whole herb medicines versus isolated constituents in the sweet wormwood (Artemisia annua L.) for malaria (Rasoanaivo et al., 2011) or the coneflower (Echinacea purpurea) for colds and flu (Chicca et al., 2009).

With the purpose of contributing to fill a gap in ethnobotanical and ethnopharmacological research, the present work studies plant combinations, otherwise known as medicinal plant mixtures, collected on ethnobotanical research programmes carried out in two districts of Catalonia, Alt Empordà and Ripollès (Parada, 2008; Rigat et al., in press). The aims of this work are: i) to perform qualitative and quantitative analyses of these mixtures; ii) to carry out a comparison among the mixtures and their floristic composition in the two Catalan territories considered; iii) to assess the worth of families association; and, iv) to evaluate whether the plants claimed to be used in mixtures have contraindications or possible negative interactions according to phytopharmaceutical literature.

The importance of the approach we propose to undertake is manifold: on the one hand, to find the appropriate method to carry out the analysis of these data so that this study can establish a protocol that can be implemented in similar cases, and on the other hand, to consider some of these mixtures as good candidates for synergy assessments in future pharmacological studies.

\section{Material and methods}

\subsection{Study areas}

Alt Empordà and Ripollès are two administrative districts (called "comarca", in plural "comarques" in the Catalan language) located in north-eastern Catalonia (Fig. 1), which together cover an extensive area of bioprospecting $\left(2,314 \mathrm{~km}^{2}\right)$ and a large altitudinal gradient, from sea level to high mountain (0-2909.8 $\mathrm{m}$ a.s.l). These two elements give rise to a wide range of flora. Although fully industrialised, in both regions rural settlements and practices are still alive. 


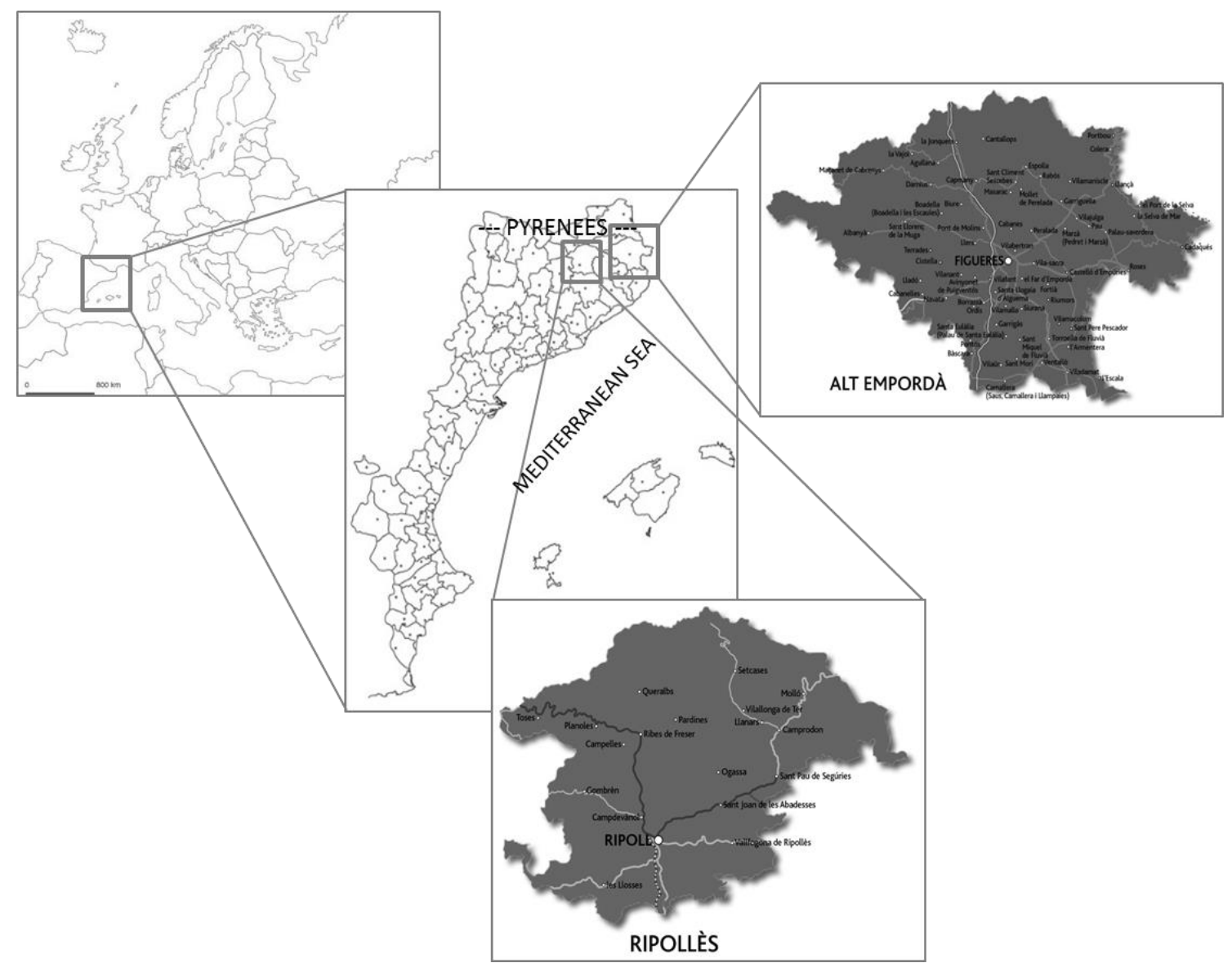

Fig. 1. Studied areas in the contexts of Europe and the Catalan linguistic domain

Alt Empordà occupies an area of $1,357.5 \mathrm{~km}^{2}$ and has 140,118 inhabitants (IDESCAT, 2016) living in 68 municipalities. The climate is mainly coastal Mediterranean. The vegetation is distributed in an asymmetrical form in two biogeographical regions: Mediterranean, largely dominant, and Eurosiberian, in certain mountainous areas, reaching 1,443 $\mathrm{m}$ a.s.l.

The Ripollès area takes up $956.6 \mathrm{~km}^{2}$ and has a population of 25,101 inhabitants (IDESCAT, 2016) distributed in 19 municipalities, with a high percentage of the population inhabiting small villages and isolated houses. Located in the eastern Pyrenees, it has a high mountain climate with Mediterranean influence. The flora and vegetation are mostly Eurosiberian, with some Boreoalpine zones in mountain areas reaching 2,909.8 m a.s.l.

\subsection{Data source and field work methods}

In this study on herbal drug combinations we have used data on medicinal plant mixtures obtained from two extensive ethnobotanical research projects carried out in the two 
Catalan districts mentioned above. On the one hand, the doctoral thesis of Parada (2008) on traditional knowledge of plants in the Alt Empordà and on the other hand, the ethnobotanical study conducted in Ripollès (Rigat et al., in press). In both cases, a long series of publications has derived from these studies (Gras et al., 2016; Parada et al., 2009, 2012; Rigat et al., 2015, 2016 and references therein).

The field work method used was the semistructured interview (Pujadas et al., 2004; Vallès et al., 2007), always taking into account the code of ethics of the International Society of Ethnobiology (International Society of Ethnobiology, 2008). Native people, mostly the elderly (over 70 years of age), were selected on a snowball basis (Bernard, 1998; Goodman, 1961), and were interviewed in Catalan, the common language to interviewees and interviewers. In Alt Empordà we carried out 101 interviews with 178 informants and in Ripollès 104 interviews with 163 informants. All interviews were digitalized, transcribed and introduced into our database (www.etnobotanica.cat) that contains all ethnobotanical data (on medicinal, food and other uses) collected since the first ethnobotanical works in 1991 until the present. It is not yet open to public access, but we plan it will be in the near future.

A voucher for each taxon was prepared and deposited at the herbaria BCN (Centre de Documentació de Biodiversitat Vegetal, Universitat de Barcelona). Voucher numbers of all taxa considered are provided in Appendixes A and B. All taxa were identified and determined according to Flora Manual dels Països Catalans (Bolòs et al., 2005) and updated according to The Plant List (http://www.theplantlist.org) for this work. Families have been assigned following APG IV (Angiosperm Phylogeny Group, 2016).

\subsection{Data analysis}

The quantitative analyses included descriptive statistics for botanical variables (species, families, part of the plant used, mode of preparation and medicinal uses) and the graphics were carried out with Excel software (Microsoft Office, 2010).

The Shannon diversity index (Shannon, 1948) has also been calculated in order to quantify the diversity of families in mixtures, thereby contemplating the number of families present in each mixture (botanical families richness), and the relative amount of species of each of these families (abundance): $\mathrm{H}_{\mathrm{fam}}=-\Sigma \mathrm{P}_{\mathrm{fam}} \log _{2} \mathrm{P}_{\mathrm{fam}}$.

Aiming to evaluate the weight of each taxon in the mixtures compared with the simple use, we have created an index. This index of taxon usefulness in mixtures (ITUM) is conceived as the quotient between the number of citations (use reports, UR) of this 
taxon in mixtures and its total citations, whether with simple or complex presentation. The value of this index will be between 0 and 1, approaching zero when the number of citations in simple presentation is superior to the number of citations in mixtures, and it will be one when the taxon appears only in mixtures.

$$
\text { ITUM }=\frac{\text { UR taxon in mixtures }}{\text { UR taxon in simple presentation }+ \text { UR taxon in mixtures }}
$$

We used the social network analysis software package Ucinet 6 and NetDraw (Borgatti et al., 2002) to analyse the direct connection among botanical families and to provide a visualization of the whole network. Data on mixtures derived from ethnobotanical studies in Alt Empordà and Ripollès have been used to construct the matrix $(66 \times 66)$ containing the botanical families present in mixtures and the number of interactions between them. Data were treated symmetrically.

Finally, the review of mixtures information provided by the informants was carried out in three steps. The first one is the estimation of the information consensus factor ( $F_{I C}$, the quotient between the number of use reports minus the number of taxa used and the number of use reports minus one; (Trotter and Logan, 1986)) for evaluating the consistency and reliability of the information recorded; the second one is the verification of the possible interactions or contraindications in mixtures (De Smet et al., 1992, 1993, 1997; Fitoterapia.net, 2016); and the third and last one is the list of the pharmacodynamic or pharmacokinetic interactions detected in the inventoried plant mixtures (EMA, 2010; ESCOP, 2003-2009).

\section{Results and discussion}

\subsection{General analyses}

The ethnobotanical study of Alt Empordà and Ripollès, based on 205 interviews with 341 informants, has derived in a total of 484 medicinal plant combinations, of which 462 are for human use (Appendix A) and 22 for veterinary use (Appendix B). These last data will be mentioned at the end of this section, but not in a very extensive way due to the scarcity of information. 
The set of 462 medicinal mixtures recorded for human medicine comprises a total of 191 taxa, five of which were determined only at generic level. All these taxa are distributed in 146 genera and 66 families.

\section{Most reported taxa}

Lamiaceae and Asteraceae are the two most represented families in number of species comprising $30.09 \%$ and $24.03 \%$ of the mixtures, respectively, followed by Malvaceae (14.94\%), Rutaceae (14.07\%) and Rosaceae (12.77\%). These results confirm the high involvement of some families such as Lamiaceae and Asteraceae in Mediterranean folk medicine, whether or not in a complex preparation (Di Sanzo et al., 2013; GonzálezTejero et al., 2007, and references therein). These families are big in terms of number of taxa, Asteraceae being the largest one (Funk et al., 2009); cosmopolitan and well represented in our territories, but also, in the case of Lamiaceae, are economically very significant, thanks to aromatic plants (Kadereit, 2012). This supports Johns et al. (1990) and Bonet et al. (1999), who postulated that the plants growing in a closed environment of a human group are probably most used. Irrespective of the relevance of Malva sylvestris in Mediterranean ethnobotany, Malvaceae used not to be in the top of the ranking of families (Parada et al., 2009 and references therein). Its appearance in the third position here is probably due to the important (and almost equal in terms of use reports) presence of the above-quoted species and Tilia platyphyllos in mixtures, but it is influenced, at least to some extent, by the relatively recent merging of family Tiliaceae into the Malvaceae (Angiosperm Phylogeny Group, 2016, and references therein).

Moerman et al. (1999), after a comparative analysis of five medicinal floras, stated that only nine plant families are needed to delineate the five most important medicinal plant families in four regions, and demonstrated the existence of a global pattern of human knowledge. Three of these five families are also common at the top of our results: Asteraceae, Apiaceae and Lamiaceae.

Concerning species and subspecies, 25 of them account for more than a half $(52.32 \%)$ of total use report of all the 191 taxa quoted (Table 1$)$. The most reported species in mixtures are Thymus vulgaris with 56 citations and present in a $12.12 \%$ of mixtures, Rosmarinus officinalis $(54 ; 11.69 \%)$ Vitis vinifera $(41 ; 8.87 \%)$ and Olea europaea and Petroselinum crispum, both with 37 citations (8.01\%). All of these species are very common and they have a wide distribution, and as such it is easy for the informants to know and obtain them. 
Some plant products have not been included as ingredients of mixtures because their use is as an excipient, a usually inert substance that forms a vehicle. Examples of this kind of products are sugar (Saccharum officinarum and Beta vulgaris subsp. vulgaris var. crassa) used to make syrups; wine and subproducts (Vitis vinifera) used to extract active substances of the plants through medicinal wine, medicinal vinegar, elixir or lotion, or olive oil (Olea europaea) employed as an embrocation or liniment. So, when we allude to Vitis vinifera in the last paragraph and in Table 1, we refer to exclusively medicinal (not just excipient) uses of parts of this plant.

Table 1

List of the twenty-five most cited species in mixtures

\begin{tabular}{|c|c|c|}
\hline Taxa (family) & Number of citations & Presence in mixtures (\%) \\
\hline Thymus vulgaris L. (Lamiaceae) & 56 & 12.12 \\
\hline $\begin{array}{l}\text { Rosmarinus officinalis L. } \\
\text { (Lamiaceae) }\end{array}$ & 54 & 11.69 \\
\hline Vitis vinifera L. (Vitaceae) & 41 & 8.87 \\
\hline Olea europaea L. (Oleaceae) & 37 & 8.01 \\
\hline $\begin{array}{l}\text { Petroselinum crispum (Mill.) } \\
\text { Fuss (Apiaceae) }\end{array}$ & 37 & 8.01 \\
\hline $\begin{array}{l}\text { Citrus limon (L.) Osbeck } \\
\text { (Rutaceae) }\end{array}$ & 34 & 7.36 \\
\hline $\begin{array}{l}\text { Althaea officinalis L. } \\
\text { (Malvaceae) }\end{array}$ & 28 & 6.06 \\
\hline Ruta chalepensis L. (Rutaceae) & 28 & 6.06 \\
\hline $\begin{array}{l}\text { Allium sativum } \mathrm{L} . \\
\text { (Amaryllidaceae) }\end{array}$ & 27 & 5.84 \\
\hline Sambucus nigra L. (Adoxaceae) & 27 & 5.84 \\
\hline $\begin{array}{l}\text { Brassica nigra (L.) K.Koch } \\
\text { (Brassicaceae) }\end{array}$ & 26 & 5.63 \\
\hline $\begin{array}{l}\text { Linum usitatissimum } \mathrm{L} . \\
\text { (Linaceae) }\end{array}$ & 23 & 4.98 \\
\hline $\begin{array}{l}\text { Hypericum perforatum L. } \\
\text { (Hypericaceae) }\end{array}$ & 22 & 4.76 \\
\hline $\begin{array}{l}\text { Aloysia citriodora } \text { Palau } \\
\text { (Verbenaceae) }\end{array}$ & 21 & 4.55 \\
\hline $\begin{array}{l}\text { Tilia platyphyllos Scop. } \\
\text { (Malvaceae) }\end{array}$ & 21 & 4.55 \\
\hline Malva sylvestris L. (Malvaceae) & 20 & 4.33 \\
\hline $\begin{array}{l}\text { Santolina chamaecyparissus L. } \\
\text { (Asteraceae) }\end{array}$ & 20 & 4.33 \\
\hline Triticum aestivum L. (Poaceae) & 20 & 4.33 \\
\hline $\begin{array}{l}\text { Lavandula angustifolia Mill. } \\
\text { (Lamiaceae) }\end{array}$ & 19 & 4.11 \\
\hline Zea mays L. (Poaceae) & 19 & 4.11 \\
\hline Arnica montana L. (Asteraceae) & 17 & 3.68 \\
\hline $\begin{array}{l}\text { Plantago major } \mathrm{L} . \\
\text { (Plantaginaceae) }\end{array}$ & 17 & 3.68 \\
\hline
\end{tabular}




\begin{tabular}{lc|c}
\hline $\begin{array}{l}\text { Plantago lanceolata } \mathrm{L} . \\
\text { (Plantaginaceae) }\end{array}$ & 16 & 3.46 \\
\hline $\begin{array}{l}\text { Rubus ulmifolius Schott } \\
\text { (Rosaceae) }\end{array}$ & 16 & 3.46 \\
\hline $\begin{array}{l}\text { Matricaria chamomilla } \mathrm{L} . \\
\text { (Asteraceae) }\end{array}$ & 14 & 3.03
\end{tabular}

\section{Richness and diversity in mixtures}

The average number of taxa or ingredients in mixtures is 2.71 , with a minimum of two and a maximum of 15 . The mixture with the highest number of ingredients is an ointment, but usually medicinal liquors form an important part. An example is the classical liqueur called ratafia, a typical Catalan beverage including Juglans regia unripe fruits, along with a number of other plant taxa, overpassing 50 in some cases (Vallès et al., 2004). In general terms, ratafia is considered a folk functional food (FFF) perceived by the informants as food and medicine in one, and it is used as a digestive and antidysmenorrhoeal (Vallès et al., in press).

The relation of taxa and families number in each mixture (Fig. 2) reflects a strong bond between the number of taxa present in each mixture and the diversity of families to which they belong, being almost equal to one. This fact leads us to affirm that there is a great diversity and richness within each mix.

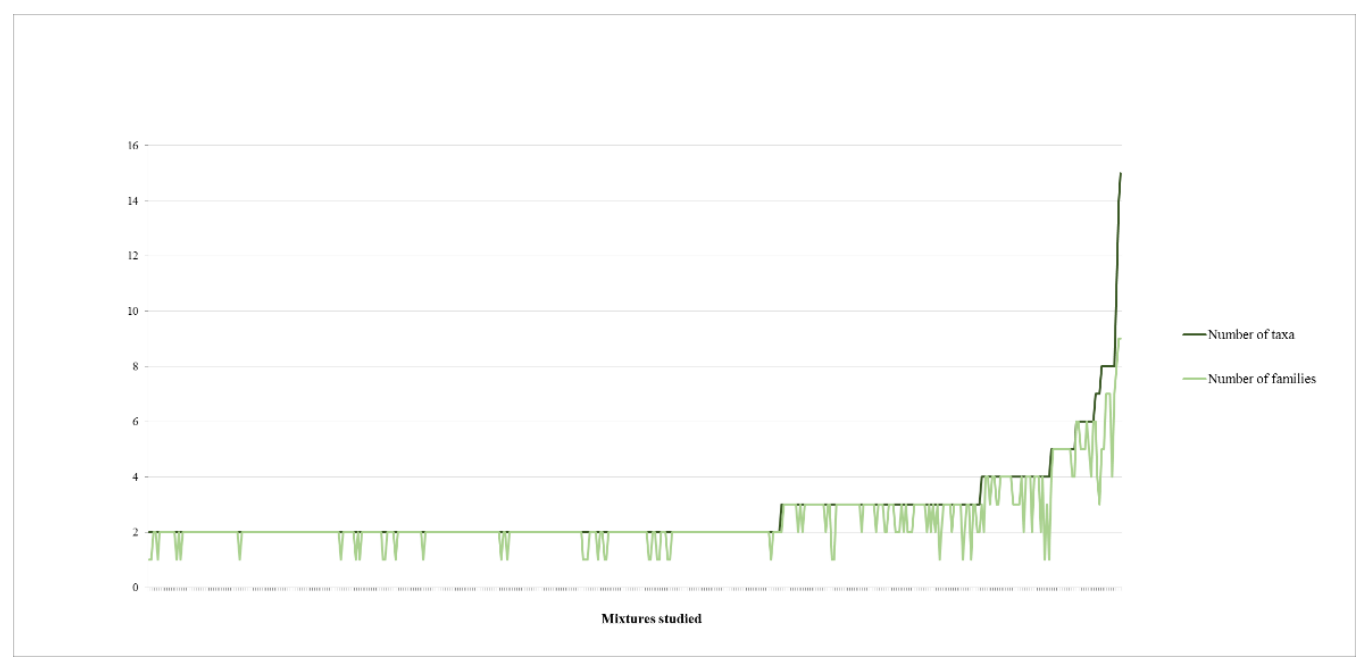

Fig. 2. Relation of taxa number and number of families present in each of 462 mixtures

In order to quantify this heterogeneity in plant combinations, an index has been calculated. The Shannon diversity index is widely used in ecology to measure specific biodiversity (Margalef, 1974), but it has also been used in studies to calculate ethnobotanical diversity based on the number of reports by species (Begossi, 1996). The 
values obtained from this expression range from 0 , when involving a mixture of all species belonging to a single family, to 0.86 maximum value. This corresponds to the mixture with the highest number of ingredients, with 15 species distributed between nine botanical families.

The index of taxon usefulness in mixtures was calculated taking into account all the taxa with more than three use reports in mixtures, thereby using the same criteria as in the simple presentation (Johns et al., 1990; Le Grand and Wondergem, 1987). The results show there are two cases, Alkanna tinctoria and Cucumis sativus, in which the numbers of use reports in simple and complex presentation are the same and the resulting value is 0.5 . There are three cases where the value is 1 and therefore the taxon exists only in this complex preparation, Hordeum vulgare, Myristica fragrans and Typha latifolia. The remaining values are distributed between $(0,1]$, with a very dissimilar proportion between $(0,0.5)$ and (0.5 to 1$]$, the first one being more frequent (Fig. 3). Finally we want to focus on Arnica montana, the third commonest taxon in a simple preparation, with an index value near zero (0.05), due to the specific and individual use of this plant as antiecchymotic. We propose this new index as an important part of any standardized protocol dealing with ethnobotanical plant mixtures.

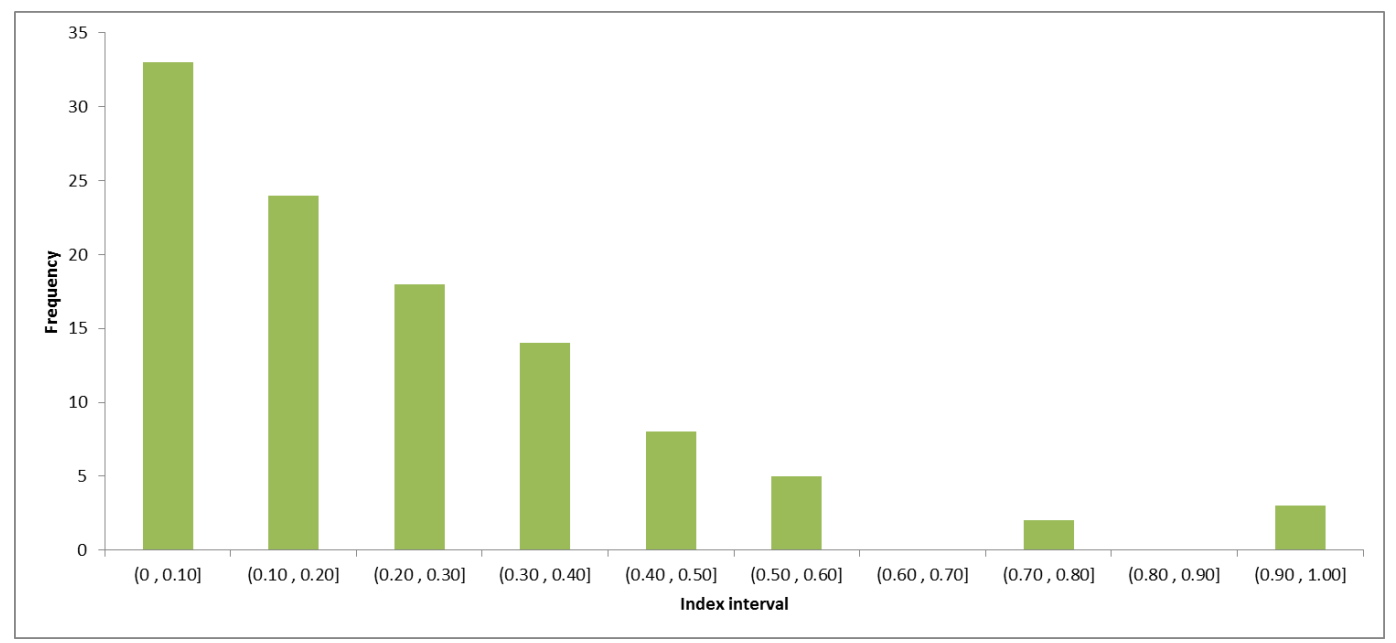

Fig. 3. Index of taxon importance results distributed on intervals

\section{Parts of plants used and pharmaceutical forms}

According to informants, different parts of the plants were used to prepare the mixtures. The most reported parts consisted of aerial parts (32.85\%), including young aerial, sterile aerial, flowering aerial and fructified aerial parts; followed by flowers and inflorescences 
$(17.55 \%)$, and fronds or leaves (12.82\%). Besides the works analysed in this study, these results are concordant with those that have been published in other areas across the Catalan language domain (Agelet, 1999; Bonet, 2001; Carrió, 2013 and references contained).

Generally, in folk medicine the preparation form is not very complex, but that does not mean it is not effective. In some other cases the preparation is more sophisticated, like syrups and essences with a more complex process of elaboration (Parada et al., 2009). In the case of mixtures, we could expect more complexity in pharmaceutical forms than in simple ethnobotanical medicines, but the same trend as in simple preparation is observed. Tisane, including infusion and decoction, is the most commonly used form, present in 186 mixtures, and represents $40.26 \%$ of forms, followed by plaster or poultice $(83 ; 17.97 \%)$ and lotion or elixir $(45 ; 9.74 \%)$. Finally, if we consider embrocation or liniment and ointment with 33 and 23 mixtures (7.14\% and 4.98\%), respectively, these five forms represent almost $80 \%$ of the total. This preference for tisanes matches with simple preparation in both districts as well as in other similar Mediterranean works (Agelet, 1999; Bonet, 2001; Cakilcioglu et al., 2011; Carrió, 2013; González et al., 2010; Maxia et al., 2008; Mulet, 1990; Muntané, 1991; Parada, 2008 and Rigat et al., in press).

The administration form in mixes shows quite similar results between oral $(50.22 \%)$ and topic $(48.70 \%)$ ways. The remaining $1.08 \%$ is unknown by the informant and could not be allocated to any group.

\section{Medicinal uses treated in mixtures}

All diseases reported as treated with plant mixtures have been grouped by organic systems disorders (Fig. 4A). Disorders of the respiratory system ranked in the first position with $26.19 \%$ of mixtures, the anticatarrhal use being the one most mentioned. Secondly, skin and subcutaneous tissue disorders $(13.85 \%)$, with external antiseptic, antiecchymotic or antipyrotic uses, and thirdly, mixtures to treat digestive system disorders (13.64\%), such as carminative, digestive or against stomach ache, among others. Overall, the majority of medicinal mixtures reported by informants is used for minor illnesses or not very serious and chronic diseases. 
The study has inventoried a small part of mixtures for veterinary use, with a total of 22 plant combinations: five in Alt Empordà and 17 in Ripollès. These data have been treated together because they are not numerous.

These mixtures are represented by 35 taxa, corresponding to 32 genera and 20 botanical families, with an average of 2.73 taxa per mix. Lamiaceae is the most present family in mixtures (36.36\%), followed by Amaryllidaceae and Poaceae with $31.82 \%$, Urticaceae with a $22.73 \%$ and Malvaceae $(22.73 \%)$. It is worth mentioning that the Asteraceae, one of the commonest families in human-addressed mixtures and, in general, in ethnobotanical remedies in the area studied, are not at the top here. Nevertheless, this family is the second most reported in ethnoveterinary (mostly considering simple preparations) in some Catalan territories, including most areas dealt with in the present study (Carrió et al., 2012).

The most cited taxon is Parietaria judaica, appearing in $10 \%$ of the mixes; this value explains the Urticaceae family among the top five, and bears a close relation to the predominant use of veterinary mixtures and the pharmaceutical form: partum and postpartum coadjuvant and tisane, with $45.45 \%$ and $40.91 \%$ respectively. This plant is reported for this use in other Catalan-speaking regions and also in Italy (Bonet and Vallès, 2007; Carrió et al., 2012; Viegi et al., 2003).

Regarding the most used part of the plant, as we have seen in the human use, the aerial part prevails, with a $46.67 \%$.

\subsection{Comparison among the studied territories}

A similar number of mixtures has been registered in both districts: 251 in Alt Empordà and 211 in Ripollès, this meaning 0.18 and 0.22 mixtures $/ \mathrm{km}^{2}$, respectively (Table 2).

The five most present families in each territory only coincide in two cases, Asteraceae and Lamiaceae, families that are also very important in the respective simple taxa analyses (Parada, 2008; Rigat et al., in press). It is also important to keep in mind the importance of these families in the flora of the study areas.

The most commonly used species are coincident only in two of the five cases, Rosmarinus officinalis and Thymus vulgaris. The strong presence of Vitis vinifera, Olea europaea and Brassica nigra in Alt Empordà, which does not match with the results of the simple presentation (Parada, 2008), is also important. One of these cases can be explained, since Brassica nigra is commonly used to make poultices with other ingredients or taxa. 
Table 2

Overall results in Alt Empordà and Ripollès districts

\begin{tabular}{|c|c|c|}
\hline & Alt Empordà & Ripollès \\
\hline Number of mixtures & 251 & 211 \\
\hline Mixtures/km² & 0.18 & 0.22 \\
\hline Total taxa & 134 & 131 \\
\hline Taxa average for mixture & 2.59 & 2.83 \\
\hline Taxa cited with medicinal use $(\%)$ & 39.22 & 45.04 \\
\hline $\begin{array}{l}\text { Families } \\
\text { (\% mixtures) }\end{array}$ & $\begin{array}{c}\text { Lamiaceae }(29.08) \\
\text { Poaceae }(14.34) \\
\text { Asteraceae }(13.94) \\
\text { Rosaceae }(13.15) \\
\text { Vitaceae }(13.15) \\
\end{array}$ & $\begin{array}{l}\text { Asteraceae }(36.02) \\
\text { Lamiaceae }(31.28) \\
\text { Malvaceae }(18.48) \\
\text { Apiaceae }(16.59) \\
\text { Rutaceae }(15.64)\end{array}$ \\
\hline $\begin{array}{l}\text { Taxa } \\
\text { (\% mixtures) }\end{array}$ & $\begin{array}{c}\text { Vitis vinifera }(13.15) \\
\text { Thymus vulgaris }(12.75) \\
\text { Rosmarinus officinalis }(11.95) \\
\text { Olea europaea }(11.16) \\
\text { Brassica nigra }(9.96) \\
\end{array}$ & $\begin{array}{c}\text { Petroselinum crispum }(12.80) \\
\text { Rosmarinus officinalis }(11.37) \\
\text { Thymus vulgaris }(11.37) \\
\text { Allium sativum }(9.95) \\
\text { Hypericum perforatum }(9.95)\end{array}$ \\
\hline Part of plant (\%) & Aerial part (25.04) & Aerial part (41.37) \\
\hline Disorders $(\%)$ & $\begin{array}{c}\text { Respiratory system disorders } \\
(31.87) \\
\text { Musculoskeletal system } \\
\text { disorders (14.74) } \\
\text { Digestive system disorders } \\
(12.75)\end{array}$ & $\begin{array}{c}\text { Respiratory system disorders } \\
\text { (19.43) } \\
\text { Skin and subcutaneous tissue } \\
\text { disorders (19.43) } \\
\text { Digestive system disorders } \\
(14.69)\end{array}$ \\
\hline
\end{tabular}

Comparing all the species recorded in each region, we could count 71 in common between Alt Empordà and Ripollès (Fig. 4B). Some of these are species with a large distribution, such as Calendula officinalis, Matricaria chamomilla, Papaver rhoeas, Sambucus nigra or Thymus vulgaris, among others, but this is not the case of Arnica montana, used in both territories, but present in its wild form only in the second. The arnica use in the Alt Empordà may be explained by different factors. The first one is transhumance between these two districts, a phenomenon widely described by Costa (1987), shepherds carrying with them not only flocks of sheep and cows, but also the traditional knowledge about plants of the territory. The second is the establishment of some original habitants of the Ripollès region in Alt Empordà, and the proximity between Alt Empordà and the axial Pyrenees, where this plant can be found from 1,200 m a.s.1. In fact, Alt Empordà's informants indicate either that they go to the mountain (usually in a place located in Ripollès) to collect the plant or that they buy it from a herbalist. 

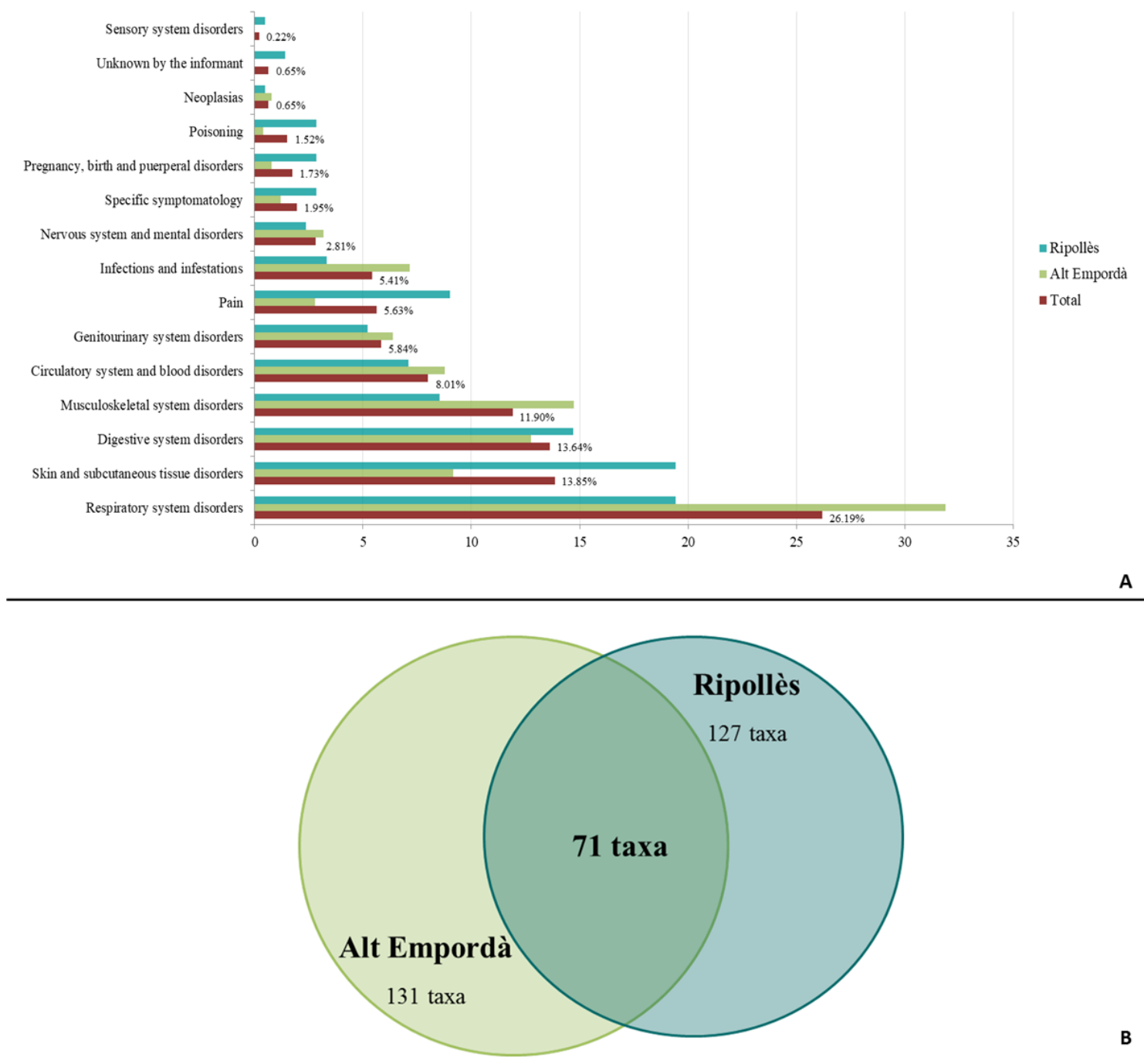

Fig. 4. (A) Disorders treated in mixtures, total and districts results (Alt Empordà and Ripollès); (B) Venn's diagram showing the number of common and exclusive species between districts

Re-examining the species separately in each territory, in Alt Empordà we find a big diversity of Lamiaceae with genera such as Lavandula, Mentha, Origanum and Salvia. The presence of Cistaceae, typical in the lower-lying Mediterranean climate areas, is relevant, and some exotic species like Aloe vera, Myristica fragrans, Syzygium aromaticum or Vanilla planifolia can be explained by the proximity to big markets. In Ripollès, we can find typical species of mountain habitats, such as Achillea pyrenaica, Antennaria dioica, Carum carvi, Eryngium bourgatii, Lilium pyrenaicum, Meum athamanticum, Ranunculus parnassifolius, Jacobaea leucophylla, Taraxacum dissectum or Thymus serpyllum.

In some cases a genus exists in both territories, with different species used in each area. For example, the genus Pinus, with P. halepensis or P. pinea in Alt Empordà, as 
opposed to $P$. sylvestris in Ripollès. This also happens with the genus Quercus, using $Q$. ilex or $Q$. suber in the lowland district and $Q$. petraea in the mountain district; or Paronychia, using P. argentea in Alt Empordà and P. kapela in Ripollès.

The most used part of the plant in both territories was the aerial part and all that that implies; the results are also coinciding with each region for simple presentations (Parada, 2008; Rigat et al., in press). The use of the root in third position in the Ripollès district with a not negligible value $(12.06 \%)$ represents a not very common fact in districts studied from the ethnobotanical viewpoint.

Finally and also in both cases, the most treated types of ailments with these mixtures are the respiratory system disorders (Fig. 4A), anticatarrhal use being the most frequent.

\subsection{Families association}

The set of results presented in the overall analysis suggests a possible trend of association between families in mixtures (Fig. 5). Having studied these families we can see that the 25 most cited species represent a $77.39 \%$ of total interactions. The most frequent association is Lamiaceae with Lamiaceae in $12.12 \%$ of mixtures, Asteraceae with Lamiaceae (11.69\%), Apiaceae with Asteraceae (4.33\%) and Brassicaceae with Linaceae (4.11\%). The first two percentages could be explained through the ingredients of the mixtures, as $9.70 \%$ of ingredients belong to the Asteraceae and $17.71 \%$ to the Lamiaceae. There exist 12 families with only one interaction, like Betulaceae, Ericaceae, Rhamnaceae or Orchidaceae, among others, and in all cases with only one taxon within the family and one report. Orchidaceae is a curious case, being one of the largest families of plants in the world -an estimation suggests approximately 25,000 species worldwide (Chase et al., 2003)- yet it generally has few uses other than as an ornamental, or as in the case of vanilla (Vanilla planifolia), used occasionally as a medicine (Moerman et al., 1999). 


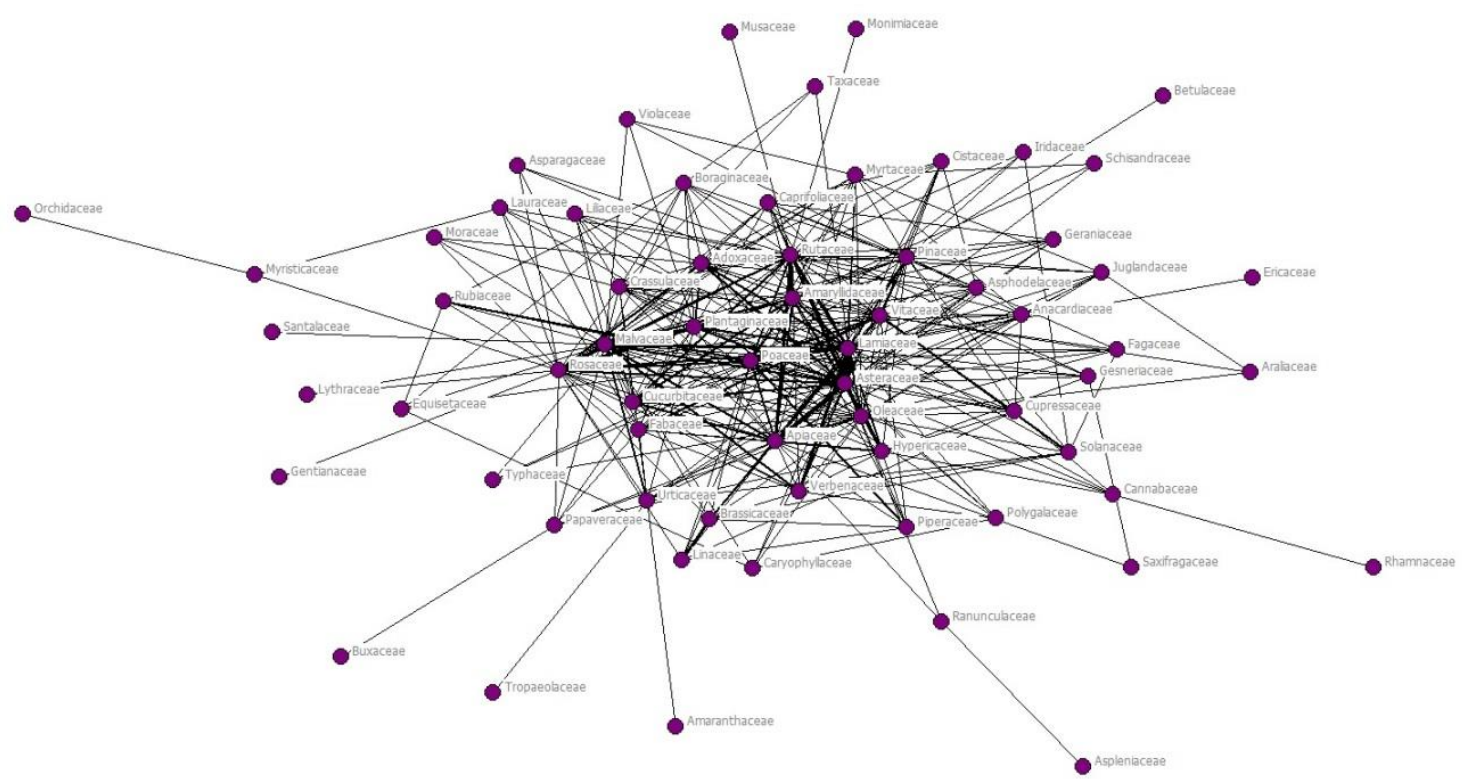

Fig. 5. Whole network visualization of families association in the 462 mixtures studied. The line width is directly proportional to the number of associations between two families

\subsection{Evaluation data with phytopharmaceutical literature}

The informant consensus factor (FIC) for our mixtures data is 0.85 , a high value that accounts for the consistency and reliability of the information reported by the interviewees (more reliable when closer to 1). Even if this value is not comparable with other studies of simple preparation, it suggests a solid information fact of popular knowledge on plant combinations with medicinal use.

To find a process to verify the possible negative interactions or contraindications in mixtures has been possible in $70 \%$ of species. Some of the remaining $30 \%$ correspond to species rarely used in herbal medicine, but widely used in the Catalan territory, such as genus Sedum, with topic use, or some species typical of the studied area like Achillea pyrenaica, Ranunculus parnassifolius or Senecio leucophyllus (Rigat et al., 2015).

According to the above-quoted sources, only three out of 188 species demonstrate contraindications in respect to the action for which the mixture has been used. These three species are Glycyrrhiza glabra, used as antihypertensive, but contraindicated in the case of hypertension, Quercus petraea, used as vulnerary and contraindicated in open wounds, and Rosmarinus officinalis, used as an external antiseptic and with the same contraindications as $Q$. petraea. However, it should be remarked that these three contraindications are only present in four mixtures and this fact shows that the informants of Alt Empordà and Ripollès have a good knowledge about plants and disease and their proper use. 
In addition, some kind of pharmacodynamic or pharmacokinetic interaction was detected in the inventoried plant mixtures (Appendix C). A total of 10 species have interactions with synthetic drugs (pharmacodynamic interactions) or other interaction forms such as absorption, metabolism or excretion problems (pharmacokinetic interactions). It is important to mention that one of the 20 most cited species, Hypericum perforatum, has a large number of interactions, keeping in mind that, years ago, when the use of these mixtures was much more frequent, the use of synthetic drugs was not, or scarcely, present.

\section{Concluding remarks}

A large volume of data concerning plant mixtures, usually not exploited in classical ethnobotanical studies, has been analysed, revealing a wide range of taxa and uses. The plant used part and preparation form do not differ so much from the results that can be found in studies of simple preparations. The main diseases treated with mixtures are disorders related to the respiratory system.

Both districts share a significant number of taxa used, but also relevant is the exclusivity of some plants in each region. In other cases a flow of traditional knowledge associated with these plants between areas has been shown.

The FIC value and the low number of taxa with contraindications, pharmacodynamic or pharmacokinetic interactions accounts for the high level of knowledge the informants have concerning these plants.

We believe this work can constitute a first step for further studies and can be useful as a protocol for addressing and highlighting these kind of data, which are so often wasted. The diversity value in mixtures, the index of taxon usefulness in mixtures (ITUM), or the frequency partnership between families could be a good beginning for adequately exploiting plant mixtures in ethnobotany and, particularly, ethnopharmacology.

To conclude, we consider this kind of ethnobotanical research a good opportunity to identify plant combinations that can be candidates for synergy assessments, as they are probably well tolerated mixtures. Furthermore, in the near future the development of standardized, safe and effective traditional herbal formulations with robust scientific evidence established from ethnobotanical data on medicinal plant associations might offer a relevant complement and impulse to the phytotherapy market.

\section{Authors' contributions}


The ethnobotanical field work was basically performed by Montse Parada and Montse Rigat, with the assistance of Teresa Garnatje and Joan Vallès. Airy Gras, Teresa Garnatje and Joan Vallès planned the study. Statistical calculations were performed by Airy Gras and Teresa Garnatje. Airy Gras wrote a first skeleton of the manuscript and then Teresa Garnatje and Joan Vallès developed some contents and produced a more advanced version. Finally, all authors read and emended the manuscript, and Airy Gras made the final version.

\section{Appendix A}

Medicinal mixtures.

\section{Appendix B}

Veterinary mixtures.

\section{Appendix C}

Pharmacodynamic and pharmacokinetic interactions.

\section{Acknowledgements}

We thank all the people who participated as informants in this work, of which they are, in fact, true collaborators, for sharing their time and knowledge. Nora Gras, Marta Palau and Salvador Cañigueral are thanked for revision support, Samuel Pyke (Barcelona's Botanic Garden) for his revision of the English language and Karina Barros (Botanical Institute of Barcelona) for providing the botanical illustrations of plants. This research was supported by projects 2014SGR00514 from the Generalitat de Catalunya (Catalan government), PRO2017-S02-VALLES from the Institut d'Estudis Catalans (IEC, Catalan Academy of Sciences and Humanities), and CSO2014-59704-P from the Spanish government. A. Gras received a predoctoral grant of the Universitat de Barcelona (APIF 2015-2018).

\section{References}

Agelet, A., 1999. Estudis d'etnobotànica farmacèutica al Pallars. PhD Thesis, Faculty of Pharmacy, University of Barcelona 
Akerreta, S., Cavero, R.Y., Calvo, M.I., 2007. First comprehensive contribution to medical ethnobotany of Western Pyrenees. Journal of Ethnobiology and Ethnomedicine 3(1), 2639.

Angiosperm Phylogeny Group, The, 2016. An update of the Angiosperm Phylogeny Group classification for the orders and families of flowering plants: APG IV. Botanical Journal of the Linnean Society 181, 1-20.

Ayurvedic Formulary of India, The, 1978. Government of India, Ministry of Health and Family Planning, Department of Health, Government of India Press, Faridabad.

Barrau, J., 1971. L'Ethnobotanique au carrefour des sciences naturelles et des sciences humaines. Bulletin de la Société Botanique de France 118, 237-248.

Begossi, A., 1996. Use of ecological methods in ethnobotany diversity indices. Economic Botany 50 (3), 280-289.

Berenbaum, M.C., 1989. What is synergy? Pharmacological Reviews 41, 93-141.

Bernard, H.R., 1998. Handbook of methods in cultural anthropology. AltaMira Press, Walnut Creek.

Bolòs, O. de, Vigo, J., Masalles, R.M., Ninot, J.M., 2005. Flora manual dels Països Catalans. Third ed. Editorial Pòrtic, Barcelona

Bonet, M.À., 2001. Estudi etnobotànic del Montseny. Doctoral Thesis, Faculty of Pharmacy, University of Barcelona

Bonet, M.À., Vallès, J., 2007. Ethnobotany of Montseny biosphere reserve (Catalonia, Iberian Peninsula): Plants used in veterinary medicine. Journal of Ethnopharmacology 10, 130147.

Borgatti, S.P., Everett, M.G., Freeman, L.C., 2002. Ucinet 6 for Windows: Software for Social Network Analysis. Harvard, MA: Analytic Technologies.

Cakilcioglu, U., Khatun, S., Turkoglu, I., Hayta, S., 2011. Ethnopharmacological survey of medicinal plants in Maden (Elazig-Turkey). Journal of Ethnopharmacology 137(1), 469486.

Carrió, E., 2013. Contribució a l'etnobotànica de Mallorca. La biodiversitat vegetal i la seva gestió en una illa mediterrània. Doctoral Thesis, Faculty of Pharmacy, University of Barcelona

Carrió, E., Rigat, M., Garnatje, T., Mayans, M., Parada, M., Vallès, J., 2012. Plant Ethnoveterinary Practices in Two Pyrenean Territories of Catalonia (Iberian Peninsula) and in Two Areas of the Balearic Islands and Comparison with Ethnobotanical Uses in 
Human Medicine. Evindence-Based Complementary and Alternative Medicine, doi: $10.1155 / 2012 / 896295$

Chase, M.W., Cameron, K.M., Barrett, R.L., Freudenstein, J.V., 2003. DNA data and Orchidaceae systematics: a new phylogenetic classi-fication, in: Dixon, K.W., Kell, S.P., Barrett, R.L., Cribb, P.J. (Eds.), Orchid conservation. Natural History Publications, Kota Kinabalu, pp. 69-89.

Chicca, A., Raduner, S., Pellati, F., Strompen, T., Altmann, K., Schoop, R., Gertsch, J., 2009. Synergistic immunomopharmacological effects of $\mathrm{N}$-alkylamides in Echinacea purpurea herbal extracts. International Immunopharmacology 9, 850-858.

Corning, P., 1998. The synergism hypothesis: On the concept of synergy and its role in the evolution of complex systems. Journal of Social and Evolutionary Systems 21(2), 133172.

Costa, E., 1987. Viatges amb els pastors transhumants. Editorial Monblanc Martin - CEC, Barcelona.

De Smet, P.A.G.M., Keller, K., Hänsel, R., Chandler, RF., 1992. Adverse Effects of Herbal Drugs. Vol. I. Springer-Verlag Berlin, Heidelberg.

De Smet, P.A.G.M., Keller, K., Hänsel, R., Chandler, RF., 1993. Adverse Effects of Herbal Drugs. Vol. II. Springer-Verlag Berlin, Heidelberg.

De Smet, P.A.G.M., Keller, K., Hänsel, R., Chandler, RF., 1997. Adverse Effects of Herbal Drugs. Vol. III. Springer-Verlag Berlin, Heidelberg.

EMA (European Medicines Agency). Annual Report of the European Medicines Agency 2010. http://www.ema.europa.eu/ema/ (accessed 12.12.2016)

ESCOP (European Scientific Cooperative on Phytotherapy), 2003-2009. The Scientific Foundation for Herbal Medicinal Products, ESCOP Monographs, Second ed., Thieme, Exeter.

Fitoterapia.net. Vademécum de Fitoterapia. http://www.fitoterapia.net (accessed 12.12.2016)

Gaddum, J.H., 1940. Pharmacology. Oxford University Press, London.

Garnatje, T., Peñuelas, J., Vallès, J., 2017. Ethnobotany, Phylogeny, and 'Omics' for Human Health and Food Security. Trends in Plant Science 22(3), 187-191.

Gertsch, J., 2011. Botanical drugs, synergy, and network pharmacology: forth and back to intelligent mixtures. Planta Medica 77(11), 1086-1098.

González, J.A., García-Barriuso, M., Amich, F., 2010. Ethnobotanical study of medicinal plants traditionally used in the Arribes del Duero, western Spain. Journal of Ethnopharmacology 131(2), 343-355. 
Goodman, L.A., 1961. Snowball sampling. The Annals of Mathematical Statistics 32, 148-170. Gras, A., Garnatje, T., Bonet, M.À., Carrió, E., Mayans, M., Parada, M., Rigat, M., Vallès, J., 2016. Beyond food and medicine, but necessary for life, too: other folk plant uses in several territories of Catalonia and the Balearic Islands. Journal of Ethnobiology and Ethnomedicine 12(1), 23-76.

Gurib-Fakim, A., 2011. Ethnobotany and the Future of R\&D on Indigenous Plant Resources.

Harley, R.M., Reynolds, T., 1992. Avances in Labiatae sciences. Royal Botanic Gardens, Kew. Harshberger, J.W., 1896. The purpose of Ethnobotany. Botanical Gazette 21, 146-158.

Hofmann, A., Schultes, R.E., 1982. Plantas de los dioses. Fondo de cultura. México, México.

IDESCAT. Institut d'Estadística de Catalunya. Generalitat de Catalunya. http://www.idescat.cat (accessed 28.01.2017).

International Society of Ethnobiology. International Society of Ethnobiology Code of Ethics (with 2008 additions). http://ethnobiology.net/code-of-ethics (accessed 28.01.2017).

Institut d'Estudis Catalans, 2007. Diccionari de la Llengua Catalana. Second ed. Institut d'Estudis Catalans, Barcelona.

Johns, T., Kokwaro, J.O., Kimanani, E.K., 1990. Herbal remedies of the Luo of Siaya District, Kenya: establishing quantitative criteria for consensus. Economic Botany 44(3), 369381.

Kadereit, J.W. (Ed.), 2012. Flowering Plants- Dicotyledons: Lamiales (except Acanthaceae Including Avicenniaceae). Vol. VII. Springer Science \& Business Media, Berlin.

Le Grand, A., Wondergem, P.A., 1987. Les phytotherapies anti-infectieuses de la foretsavane, Senegal (afrique occidentale) I. Un inventaire. Journal of Ethnopharmacology 21(2), $109-125$.

Margalef, R., 1974. Ecología. Ediciones Omega, Barcelona

Maxia, A., Lancioni, M.C., Balia, A.N., Alborghetti, R., Pieroni, A., Loi, M.C., 2008. Medical ethnobotany of the Tabarkins, a Northern Italian (Ligurian) minority in south-western Sardinia. Genetic Resources and Crop Evolution 55(6), 911-924.

Moerman, D.E., Pemberton, R.W., Kiefer, D., Berlin, B., 1999. A comparative analysis of five medicinal floras. Journal of Ethnobiology 19(1), 49-70.

Mulet, L., 1990. Aportaciones al conocimiento etnobotánico de la provincia de Castellón. Doctoral Thesis, Faculty of Pharmacy, University of València

Muntané, J., 1991. Aportació al coneixement de l'etnobotànica de Cerdanya. Doctoral Thesis, Faculty of Pharmacy, University of Barcelona 
Parada, M., 2008. Estudi etnobotànic de l'Alt Empordà. Doctoral Thesis, Faculty of Pharmacy, University of Barcelona

Parada, M., Carrió, E., Bonet, M.À., Vallès, J., 2009. Ethnobotany of the Alt Emporda region (Catalonia, Iberian Peninsula): plants used in human traditional medicine. Journal of Ethnopharmacology 124(3), 609-618.

Parada, M., Carrió, E., Vallès, J., 2012. Ethnobotany of food plants in the Alt Emporda region (Catalonia, Iberian Peninsula). Journal of Applied Botany and Food Quality 84(1), 1125 .

Pardo-de-Santayana, M., Pieroni, A., Puri, R.K. (Eds.), 2010. Ethnobotany in the new Europe. People, Health and Wild Plant Resources, Berghahn Books, New York and Oxford.

Portères, R., 1970. Cours d'Ethno-botanique et Ethno-zoologie (1969-1970). Vol. I, Ethnobotanique générale. Muséum National d'Histoire Naturelle (Laboratoire d'Ethnobotanique et Ethno-zoologie), Faculté des Lettres (Institut d'Ethnologie), Paris.

Pujadas, J.J., Comas, D., Roca, J., 2004. Etnografia. Universitat Oberta de Catalunya, Barcelona.

Rasoanaivo, P., Wright, C. W., Willcox, M.L., Gilbert, B., 2011. Whole plant extracts versus single compounds for the treatment of malaria: synergy and positive interactions. Malaria Journal 10(1), S4.

Rigat, M., 2005. Estudi etnobotànic de la Vall de Camprodon (Alta Vall del Ter, Pirineus). Treball de màster experimental en Ciències farmacèutiques (especialitat Botànica), Facultat de Farmàcia, Universitat de Barcelona.

Rigat, M., Bonet, M.À., Garcia, S., Garnatje, T., Vallès, J. 2007. Studies on pharmaceutical ethnobotany in the high river Ter valley (Pyrenees, Catalonia, Iberian Peninsula). Journal of Ethnopharmacology 113(2), 267-277.

Rigat, M., Gras, A., D’Ambrosio, U., Garnatje, T., Parada, M., Vallès, J., 2016. Wild food plants and minor crops in the Ripollès district (Catalonia, Iberian Peninsula): potentialities for developing a local production, consumption and exchange program. Journal of Ethnobiology and Ethnomedicine 12(1), 49-65.

Rigat, M., Gras, A., Vallès, J., Garnatje, T., 2017. Estudis etnobotànics a la comarca del Ripollès (Pirineu, Catalunya, península Ibèrica. Collectanea Botanica (Barcelona), in press.

Rigat, M., Vallès, J., D’Ambrosio, U., Gras, A., Iglésias, J., Garnatje, T., 2015. Plants with topical uses in the Ripollès district (Pyrenees, Catalonia, Iberian Peninsula): ethnobotanical survey and pharmacological validation in the literature. Journal of Ethnopharmacology 164,162-79. 
Shannon, C.E., 1948. A mathematical theory of communication. The Bell System Technical Journal 27, 379-423, 623-656.

Trotter, R.T., Logan, M.H., 1986. Informant consensus: a new approach for identifying potentially effective medicinal plants, in: Etkin N.L. (Ed.), Plants in Indigenous Medicine and Diet, Behavioural Approaches. Redgrave Publishing Company, Bredford Hills, pp. 91-112.

Ulrich-Merzenich, G., Panek, D., Zeitler, H., Wagner, H., Vetter, H., 2009. New perspectives for synergy research with the "omic"-technologies. Phytomedicine 16(6), 495-508.

Vallès, J., Bonet, M.À., Agelet, A., Selga, A., 2004. “Quaranta dies en alcohol a sol i serena”... y el sabor embotellado: la "ratafia", licor catalán de plantas aromáticas, in: Garrido, A. (Ed.), El sabor del sabor: hierbas aromáticas, condimentos y especias. Publicaciones de la Universidad de Córdoba, Córdoba, pp. 255-276.

Vallès, J., D’Ambrosio, U., Gras, A., Parada, M., Rigat, M., Serrasolses, G., Garnatje, T., 2017. Medicinal and food plants in ethnobotany and ethnopharmacology: folk functional foods in Catalonia (Iberian Peninsula), in: Muñoz-Torrero, D., Riu, M. \& Feliu, C. (Eds.), Recent Advances in Pharmaceutical Sciences VII, Transworld Research Network, Trivandrum, in press.

Vallès, J., 2007. La recerca en etnobotànica a Catalunya: objectius, mètodes, zones estudiades i alguns resultats i comentaris generals. RIDEC (Recerca i Difusió de 1'Etnologia Catalana), 26-III-2007: 1-10.

Viegi, L., Pieroni, A., Guarrera, P.M., Vangelisti, R., 2003. A review of plants used in folk veterinary medicine in Italy as basis for databank. Journal of Ethnopharmacology 89, 221-244.

Wagner, H., Ulrich-Merzenich, G., 2009. Synergy research: Approaching a new generation of phytopharmaceuticals (Review, part I). Phytomedicine 16(2-3), 97-110.

Williamson, E.M., 2001. Synergy and other interactions in phytomedicines. Phytomedicine 8(5), 401-409. 